\title{
Matematik Dersine Bağlıık Ölçeği’nin Türkçeye Uyarlama Çalışması
}

\author{
Sacide Güzin Mazman Akar ${ }^{1}$, Osman Birgin², Büşra Göksu ${ }^{3}$, \\ Kübra Uzun ${ }^{4}$, Büşra Gümüş ${ }^{5}$ ve Elif Seval Peker ${ }^{6}$ \\ Makale geliş tarihi: 10 Temmuz 2016 \\ Yayına kabul tarihi: 21 Aralık 2016 \\ Çevrimiçi yayın tarihi: 22 Ocak 2017
}

Öz: $\mathrm{Bu}$ araştırmanın amacı Rimm-Kauffman (2010) tarafından geliştirilen "Matematik Dersine Bağlılık Ölçeği”ni Türkçeye uyarlamak, geçerlik ve güvenirlik çalışma sonuçlarını ortaya koymaktır. Çalışma grubunu "Matematik Dersine Bağlılık Ölçeği'ni” yanıtlayan 602 ortaokul öğrencisi oluşturmaktadır. Orijinal ölçek 13 madde ve üç faktörden (sosyal, duyuşsal ve bilişsel) oluşmaktadır. Ölçeğin test tekrar test güvenirlik katsayısı .591 hesaplanırken, iç tutarlılık katsayısı .872 olarak elde edilmiş ve maddelerin birbiri ile ilișkisini gösteren madde-toplam korelasyonlarının .30 ile .66 arasında değer aldığı saptanmıștır. Ölçeğin yapı geçerlik çalışmaları için birinci ve ikinci düzey doğrulayıcı faktör analizleri yapılmıștır. Yapılan doğrulayıcı faktör analizleri sonunda ölçeğin orijinal ölçekteki gibi "sosyal", "bilişsel" ve "duyuşsal" bağlllık olmak üzere üç faktörden oluştuğu doğrulanmış ve kurulan modellerin iyi uyum gösterdiği belirlenmiştir. Analizler sonucunda, ölçeğin Türkçe formunun geçerli ve güvenilir bir ölçme aracı olarak matematik bağlılığı ile ilgili çalıșmalarda kullanılabilir olduğu ifade edilebilir.

Anahtar Kelimeler: Öğrenci bağlılı̆̆ı, matematik dersine bağlılık, ölçek uyarlama, geçerlik ve güvenirlik

DOI: $10.16949 /$ turkbilmat.286926

\begin{abstract}
The purpose of this study is to adapt "Student Engagement in Mathematics Scale", developed by Rimm-Kauffman (2010), into Turkish and to determine validity and reliability of the scale in Turkish form. The study group is consisted of 602 secondary school students. The original scale consisted of 13 items with three factors (social, emotional and cognitive). Adapted scale's test-retest reliability coefficient was found .591 and Cronbach alpha value was found .872. Item-total correlations of scale items ranged between .30 to .66. First order and second order confirmatory factor analyses were executed for construct validity. As a result of confirmatory factor analyses, the scale was confirmed consisting of three factors namely "social", "cognitive" and "emotional" as in original scale. These results showed that Turkish form of the scale, being reliable and valid, can be used in studies related to mathematics engagement.
\end{abstract}

Keywords: Student engagement, math engagement, scale adaptation, validity and reliability

See Extended Abstract

\section{Giriș}

Matematik hem günlük yaşamda hem de eğitim alanında oldukça önemli yer tutan bilimdir. Nitekim gerek uluslararası standart testlerle gerekse ulusal düzeyde yapılan değerlendirmelerde matematiğin çoğu zaman bireyler tarafından zor algılanan bir ders olduğu ve başarının sadece belirli bölgelerde değil evrensel olarak beklenilenin altında

\footnotetext{
${ }^{1}$ Yrd. Doç. Dr., Uşak Üniversitesi, Eğitim Fakültesi, Bilgisayar ve Öğretim Teknolojileri Eğitimi, Türkiye, guzin.mazman@usak.edu.tr

${ }^{2}$ Doç. Dr., Uşak Üniversitesi, Eğitim Fakültesi, İlköğretim Matematik Eğitimi, Türkiye, osman.birgin@usak.edu.tr

${ }^{3}$ MEB, 4 Eylül A.S.Ö. Ortaokulu, Manisa, Türkiye, busragoksu35@gmail.com

${ }^{4}$ MEB, Kestel Ortaokulu, Kütahya, Türkiye, uzunkubral6@gmail.com

${ }^{5}$ MEB, İlyaslı Ortaokulu, Uşak, Türkiye, busragumus314@gmail.com

${ }^{6}$ MEB, Saraycık Ortaokulu, Uşak, Türkiye, elifs.yldrm@gmail.com
} 
olduğu belirtilmektedir (Mohamed \& Waheed, 2011; Organization for Economic Cooperation and Development [OECD], 2004).

Matematik dersindeki öğrenci başarı ve performansının ardışık olarak ilköğretim, ortaöğretim, lise ve yükseköğrenim gibi ilerleyen dönemlerde birbirini etkilemesi nedeniyle gelecekteki meslek seçiminin belirlenmesinde olduğu gibi birçok alanda kritik öneme sahiptir. Matematik başarısını etkileyen çalışmaların daha çok lise ve üniversite öğrencilerini kapsadığı fakat özellikle ilkokul ve ortaokul gibi erken dönemler için önemli olduğu vurgulanmaktadır. Bu nedenle matematik başarısını etkileyen çalışmalar özellikle öğrencilerin geleceklerine yön vermeye ilişkin kararların alınmaya başlaması aşaması olan ortaöğretim dönemlerinde yapılması önem taşımaktadır (Singh, Granville, \& Dika, 2002).

İlköğretim yıllarından itibaren üniversite eğitimine kadar öğrencilerin matematik dersinden başarısız olmaları önemli bir sorundur. Ülkemizde de 8.sınıflar için yapılan TEOG (Temel eğitimden orta öğretime geçiş) sınav sonuçları incelendiğinde matematik dersinin ortalama güçlük indeksinin 0.42 olduğu ve diğer dersler arasında en zorlanılan ders olduğu görülmektedir (Milli Eğitim Bakanlığı [MEB], 2016). Uluslararası sınavlarda Türkiye, matematik ortalama başarısı bakımından PISA 2003 projesine katılan 30 OECD üyesi ülke arasında 28. sirada yer alırken, OECD üyesi olan ve olmayan toplam 40 ülke arasında 36. sırayı Uruguay ve Tayland ile paylaşmaktadır. Matematik başarı puanına göre TIMMS 2011'de katılan 42 ülke arasında Türkiye 24. sırada yer almış olup 452 puanla ortalamanın altında kalmıştır (Büyüköztürk, Çakan, Tan ve Atar, 2014).

Matematik başarısını etkileyen faktörlerle ilgili uzun süreden beri birçok araştırma yapılmış olup, bu araştırmalarda en çok ele alınan faktörler arasında öğrencilerin yeteneği, tutum, alg1, inanç, motivasyon, öz düzenleme, benlik kavramı, öz güven, öz-yeterlilik sosyo-ekonomik değişkenler, ebeveyn ve akran etkisi, okul ile ilgili değişkenler olduğu dikkat çekmektedir (Nicolaidou \& Philippou, 2003; Singh, Granville \& Dika, 2002). Öğrencilerin matematiğe karşı olumsuz tutum ve inanca sahip olmaları ve bunun neticesinde başarısız olmalarının birçok farklı nedeni olabilmektedir. Bu nedenler arasında genel olarak kayg1, korku, tutum, motivasyon vb. bireysel faktörler olabileceği gibi öğretmen, aile eğitim düzeyi, zorluk düzeyi, öğretim yöntemi ve çevre baskısı gibi bir çok dışsal faktörler de yer almaktadır (Baki, 2008; Birgin, Baloğlu, Çatlığlu \& Gürbüz, 2010; Dursun \& Dede, 2004; Ma, 1997; Papanastasiou, 2002; Peker \& Mirasyedioğlu, 2003; Savaş, Taş \& Duru, 2010; Singh, Granville, \& Dika, 2002).

İlgili alan yazın çalışmalarından görüldügü gibi öğrencilerin matematik başarısını ve başarısızlığını etkileyen faktörler oldukça fazla olmakla birlikte bu faktörlerden biri de yapılan çalışmalarda öğrenci başarısı ile oldukça yakından ilişkili olduğu görülen bağlılık (engagement) kavramıdır. Öğrencilerin matematik dersindeki bağlılığını arttırmanın aynı zamanda matematik dersindeki başarılarını da arttıracağı ve bağlılığı ortaya koymanın süreçteki motivasyonun da gösteresi olacağı ifade edilmektedir (Leis, Schmidt \& RimmKaufman, 2014; Reeve, Jang, Carell, Jeon \& Barch, 2004). 


\section{1. Öğrenci Bağlılığı}

Öğrenci bağl1lığı öğrenme sürecine bağlanma ve dahil olma, okul ile kendini özdeşleştirme, aidiyet hissetme, ayrıca okul ortamına katılım ve beklenilen akademik, sosyal ve duyuşsal öğrenme çıktıları ile ilişkili sonuçlara ulaşma olarak tanımlanmaktadır (Christenson ve ark., 2008). Ayrıca, bağlılık farklı çalışmalarda öğrencilerin görev sürecindeki harcadıkları süre ve etkinliklere katılımdaki gönüllülükleri (Stovall, 2003), öğrencilerin kendilerini, doğrudan beklenilen öğrenme çıktılarına katkıda bulunan eğitsel amaçlı etkinliklere adamadaki çabaları (Krause \& Coates, 2008), eğitsel faaliyetlerle meşgul olma derecesi olarak tanımlanmakta olup, bağlılığın yüksek not, öğrenci memnuniyeti, azim gibi beklenilen sonuçlarla pozitif ilişkili olduğu ifade edilmektedir (Chen, Gonyea \& Kuh, 2008).

Eğitimciler ve araştırmacılar bağlılı̆̆ın öğrenme için oldukça önemli olduğunu kabul etmekte ve bağlılığın okul başarısını etkilediğine ilişkin oldukça kapsamlı çalışmalar bulunmaktadır (Fredricks, Blumenfeld \& Paris, 2004; Günüç \& Kuzu, 2015; Hughes \& Kwok, 2007; Leis, Schmidt \& Rimm-Kaufman, 2014; Wang \& Holcombe, 2010).

Öğrencinin bağlılığının sosyal bağlam içinde anlaşılabileceği olduğu ifade edilmekte ve bu nedenle bireyin öğrenme aktivitelerine ne derece bağlı olduğunun doğrudan bireyin sınıf ortamı ve okul bağlamı ile ilgili olduğu ileri sürülmektedir (Cleary \& Zimmerman, 2012). Öğrencilerin özellikle sınıf içinde eğitsel öğrenme ortamındaki bağlılığının önemi üç temel noktada vurgulanmaktadır (Skinner \& Pitzer, 2012):

- İlk olarak, dersteki bağlılık öğrencilerin öğrenme süreci için gerekli bir koşuldur. Çünkü öğrenciler akademik etkinliklere hem bedensel hem de zihinsel olarak aktif katılırsa sınıfta harcanan zaman bilgi ve beceri kazanımı ile sonuçlanır.

- İkinci olarak bağl1lık öğrencinin okuldaki günlük deneyimini hem sosyal hem de psikolojik olarak şekillendirir. Niteliği yüksek bağlılık ve bunun sonucundaki öğrenme ile eğitsel başarı öğrencinin akademik olarak kendini daha yetkin ve ilişkili hissetmesini sağlar, öğretmenden daha olumlu etkileşim ve destek sağlar. Ayrıca derste bağlılığı yüksek öğrenciler diğer öğrencilerle arkadaş ve akran gruplarına katılırlar.

- Üçüncü olarak bağlılık öğrencilerin akademik gelişiminde önemli katk1 sağlar. Bağlılık günlük akademik esnekliğin bir parçası olup öğrencilerin günlük stres, zorluk ve tersliklerle başa çıkmasına yardımcı bir enerji kaynağıdır.

Christenson ve arkadaşları (2008) bağlılığın çok boyutlu bir yapı olduğunu ifade ederek bu boyutları akademik, bilişsel, davranışsal ve duyuşsal olarak gruplandırmışlardır. Ayrıca bu boyutlar için görev tamamlama ve çalışma verimliliği (akademik bağl1lık), sınıf içi katılım (davranışsal bağlılık), kendini yansıtma ve öğrenme etkililiğinin değerlendirilmesi (bilişsel bağlılık) ya da kendini okul ait hissetme (duyuşsal bağl1lık) gibi unsurların bağl1lık için gösterge olduğunu belirtmişlerdir. Willms (2003) ise öğrenci 
bağlılığının davranışsal ve psikolojik olmak üzere iki alt boyutu olduğunu ileri sürerek, davranışsal bağglılığı, öğrenme ortamı ile ilgili tüm etkinliklere dahil olma, psikolojik bağl1lı̆̆ ise öğrencinin kendini ortama ait hissetmesi olarak tanımlamıştır. Finn (1989) ile Fredricks ve arkadaşları (2004) ise davranışsal, duyuşsal ve bilişsel olmak üzere öğrenci bağlılığın üç temel boyuttan oluştuğunu açıklamaktadırlar.

$\mathrm{Bu}$ çalışmada kapsamında ele alınan ölçekteki bağl1lık boyutları ise Rimm-Kauffman (2010) tarafindan matematik dersi bağlamında sosyal, bilişsel ve duyuşsal olmak üzere üç başlık altında toplamıştır.

\section{Sosyal Bă̆lllık}

Sosyal bağlılık davranışa ilişkin yazılı ya da yazılı olmayan sınıf kurallarına uymayı içerir. Örneğin, okula ve sınıfa zamanında gelmek, öğretmenlerle ve akranlarla uygun etkileşim kurmak, öğrenme etkinliklerinden ayrılma ya da diğer öğrencilerin çalışmalarında rahatsız etme gibi anti-sosyal davranışların sergilenmemesi gibi davranışlarını içerir. Sosyal bağlılığın yüksek olması öğrenmeyi kolaylaştırabilirken, buna karşın sosyal bağlılığın düşük olması başarısızlığa neden olabilmektedir (Finn \& Zimmer, 2012). Sosyal bağlılık öğrenme ortamında tartışmalara katılım ya da akranları dinlemek gibi davranışsal bağlılığı da içermekle birlikte, uyumlu ve saygılı çalışmak ve diğer öğrencileri öğrenme sürecinde destelemek gibi üst düzey sosyal davranışları da içine almaktadır. Bu nedenle sosyal bağlılık, öğrencinin bağlılığını doğrudan geliştiren üst düzey sosyal etkileşimleri ve işbirlikli akran öğrenmelerini desteklemektedir (Pekrun \& Linnenbrink-Garcia, 2012).

\section{Duyuşsal Băglllık}

Duyuşsal bağlılık öğrencilerin okula ve okul ile ilgili çalışmalara karşı his ve tutumlarla birlikte diğer öğrencilerle ve öğretmenleriyle olan ilişkilerini kapsamaktadır (Bingham \& Okagaki, 2012). Duyuşsal bağlılığın ait olma hissi ve öğretim amaçlarını kabul etmenin yanında öz-yeterlilik, beklentiler, ilgi, sürece dahil olma, algılanan kontrol ve özerklik gibi unsurları da kapsadığı belirtilmektedir (Kong, Wong \& Lam, 2003).

Duyuşsal bağlılık boyutu öğrencinin "kendini okulu topluluğunun önemli bir parçası olarak görme, kendine okula ait hissetme" ile birlikte "okulu hem sosyal bir kurum hem de kişisel gelişimi sağlayan bir araç olarak tanıma"yı içerir. Bu iki öğenin ise ait olma hissi ve değer verme olarak iki temel yapıyı oluşturduğu ifade edilmektedir (Finn \& Zimmer, 2012). Ayrıca duyuşsal bağlılığın genel olarak öğrencilerin okula, akademisyenlere, sınıf arkadaşlarına, öğretmenlerine yönelik olumlu ya da olumsuz tepkileri içerdiği ve bir iş yapmak için ya da bir kurum ile bağ kurmak için istekli olmayı da etkilediği vurgulanmaktadır.

\section{Bilişsel Bağlllık}

Bilişsel bağlılık öğrenmeye ilişkin içsel motivasyonu ve kullanılan üst bilişsel stratejilerle birlikte karmaşık fikirlerin anlaşılması için enerji sarf etmeyi kapsar (Bingham \& Okagaki, 2012). Bilişsel bağlılığın göstergeleri kavramların netleşmesi için soru sorma, zor görevlerde sebat etme, verilen ödevden daha fazlasını okuma, önceden öğrenilen 
materyalleri gözden geçirme, istenilen bilgiden daha fazla bilgi kaynağına ulaşma ve öğrenmeyi yönlendirmek için bilişsel stratejilerle birlikte öz düzenleme stratejilerini kullanma eylemleridir (Finn \& Zimmer, 2012). Ayrıca bilişsel bağlılık öğrenme, düşünme ve problem çözme stratejileri ile birlikte ele alınmakta olup, öğrenme yaklaşımları ile de yakından ilişkilidir (Kong, Wong \& Lam, 2003).

Öğrenci bağlılı̆̆ına ilişkin ölçek geliştirme ve uyarlama çalışmaları ile ilgili literatür incelendiğinde öğrenci bağlılığını farklı boyutlarını ele alan çalışmalara rastlanmaktadır (Günüç \& Kuzu, 2015; Klaasen, Yerdelen \& Durksen, 2013; Mazer, 2013). Klaasen, Yerdelen ve Durksen (2013) tarafindan geliştirilen ölçekte öğrenci bağlllığı bilişsel, duyuşsal ve sosyal bağlılık olarak 3 boyutta ele alınmıştır. Uğur ve Akın (2015), Mazer (2013) tarafından geliştirilen “Öğrenci Bağlılı̆ğ Ölçeği”ni Türkçeye uyarlamıştır. Ölçeğin orjinali 13 maddeden ve dört alt boyuttan (etkin dinleme, sözel katılım, ders içeriği hakkında düşünme, sınıf dışı çalışma) oluşmaktadır. Ergün ve Usluel (2015), Sun \& Rueda (2012) tarafından geliştirilen, davranışsal, bilişsel ve duyuşsal bağlılık olmak üzere üç faktörden oluşan 19 maddelik "Öğrenci Bağlılık Ölçeği”"ni Türkçeye uyarlanmıştır. Doğan (2014), “Öğrenci Bağlılık Ölçeği’nin Geçerlik ve Güvenirliği” adlı çalışmasında duygusal, davranışsal ve bilişsel bağlılık olmak üzere yine üç boyuttan oluşan 31 maddelik bir ölçek geliştirmişlerdir.

Alan yazın incelendiğinde Türkiye'de öğrenci bağlılı̆̆ını ortaya koymak üzere geliştirilen veya uyarlanan ölçme araçları bulunmasına rağmen bu ölçeklerin genel akademik bağlılı̆̆ 1 ölçtüğü görülmektedir. Diğer yandan matematik diğer birçok alanla ilişkili olup kitle eğitiminde oldukça önemli bir rolü vardır. Dolayısıyla öğrencinin matematik dersi kapsamında ilgisini ve ilişkisi kesmesi öğrenme sürecinde ciddi sorun ve zorluklara neden olmaktadır. Bu nedenle matematik öğrenme sürecindeki öğrenci bağlılığ kavramının ve yapılarının araştırılması oldukça önem taşımaktadır. (Kong, Wong \& Lam, 2003). Bu noktadan hareketle bu çalışmada öğrencilerin bir matematik dersinin ardından matematiğe ilişkin bağlılık düzeyini ölçen, Rimm-Kauffman (2010) tarafindan geliştirilen “Matematik Dersine Bağlılık Ölçeği'nin Türkçeye uyarlanması ve geçerlik güvenirlik çalışma sonuçlarının ortaya konulması amaçlanmıştır.

\section{Yöntem}

\subsection{Orijinal Ölçek}

"Matematik Dersine Bağlılık" ölçeği Rimm-Kaufman (2010) tarafından öğrencilerin matematik dersi bağlılıklarını bilişsel, sosyal ve duyuşsal olmak üzere üç temel alanda belirlemek üzere geliştirilmiştir. Ölçek geliştirme çalışması 5. sınıf öğrencileri ile yapılmış fakat ölçeğin benzer yaş gurubunda olan daha genç ya da daha büyük öğrencilere de uygulanabileceği belirtilmiştir. Ölçeğin sosyal bağlılık boyutundaki maddeler Patrick, Ryan \& Kaplan (2007), tarafından geliştirilen "Öğrencilerin Sosyal Bağlılık Algısı Ölçeği'nden (Student-Report Measure of Social Engagement)" uyarlanmıştır. Ölçeğin bilişsel ve duyuşsal boyutları ise Kong, Wong ve Lam (2003), Meece (2009), Rowley, 
Kurtz-Costes, Meyer ve Kizzie (2009), Skinner ve Belmont (1993) tarafindan yapılan çalışmalardan yararlanarak geliştirilmiştir. Ölçek 387 beşinci sınıf öğrencisi ile geliştirilmiştir. İlk olarak ölçekte 15 madde yer almış, madde tepki kuramına dayalı modellerden "Kısmi Puan Modeli" ile yapılan analizler sonucunda bilişsel bağlılık boyutu altında yer alan iki maddenin faktör yükünün düşük çıkması ile maddeler ölçekten çıkarılmıştır. Sonuç olarak bilişsel bağlılık boyutunda 4 madde, sosyal bağlılık boyutunda 4 madde ve duyuşsal bağlllık boyutunda 5 madde olmak üzere toplamda 13 maddelik ölçeği geliştirmişlerdir. Ölçekten elde edilen ölçümlerin güvenirliği için hesaplanan Cronbach alpha katsayıları bilişsel bağlılık boyutu için .89, duyuşsal bağlılık boyutu için .91 ve sosyal bağl1lık boyutu için .98 olarak bulunmuştur.

Ölçek 4'lü likert tipinde hazırlanmış olup maddeler "Katılmıyorum” ve "Tamamen Katılıyorum" arasında derecelendirilmiştir. Ölçekte bir madde ters madde olarak yazıldığından, ölçek puanlaması yapılırken madde tersine puanlanmıştır. Ölçekten alınabilecek maksimum puan 52, minimum puan ise 13 'tür. Ölçek puanın yüksek olmas1 matematik dersine bağlılığında yüksek olduğunu göstermektedir.

\section{2. Ölçeğin Türkçeye Çeviri Çalışmaları}

Ölçek uyarlama çalışmaları için öncelikle Rimm- Kaufman (2010)'dan e-posta yoluyla izin alınmıştır. Ardından orijinal İngilizce ölçek üç dil uzmanı ve üç alan uzmanı tarafından Türkçeye çevrilmiştir. Elde edilen çevirilerden ölçeğin ilk taslak hali oluşturulmuştur. Elde edilen taslak form üç alan uzmanı ve bir ölçme ve değerlendirme uzmanın görüşleri alınarak revize edilmiştir. Ölçeğin son hali bir dil uzmanı tarafindan tekrar İngilizceye çevrilerek orijinal form ile tutarlılığ kontrol edilmiştir. Son olarak elde edilen Türkçe ölçeğin ilgili yaş grubundaki öğrencilerce anlaşılırlığını kontrol etmek amaciyla 5 ortaokul öğrencisine ölçek birebir görüşme ile uygulanarak her maddeden ne anladığına ilişkin sorular sorularak madde eş değerliği teyit edilmiştir.

Uygulama iki aşamada gerçekleştirilmiştir. Birinci uygulama test tekrar test güvenirliği için ortaokul öğrencilerinden oluşan 40 kişiyle yapılmış, on tanesi eksik doldurulduğu için geçersiz sayılmış ve 30 ortaokul öğrencisinin verdiği yanıtlar değerlendirmeye alınmıştır. İkinci uygulama, Uşak ilinde öğrenim görmekte olan 602 ortaokul öğrencisi ile gerçekleştirilmiştir.

\subsection{Katılımcılar}

Araştırmanın verileri Uşak ilinde öğrenim gören toplam 602 ortaokul öğrencisinden elde edilmiştir. Araştırmaya katılan öğrencilerin 106'sı (\%17.6) beşinci sınıf öğrencisi, 162'si (\%26.9) altıncı sınıf öğrencisi, 188'i (\%31.2) yedinci sınıf öğrencisi, 146’s (\%24.3) sekizinci sınıf öğrencisidir. Ölçeğin uygulandığı gruptaki öğrencilerin 303'ü kız, 299'u erkek öğrencidir. Yerleşim yeri bakımından 332'si (\%55.1) köy ve belde, 213'ü (\%35.4) ilçe merkezi, 57'si (\%9.5) il merkezinde öğrenim görmektedir. 


\subsection{Veri Toplama Aracı}

$\mathrm{Bu}$ çalışmada veri toplama aracı olarak "Kişisel Bilgi Formu" ve "Matematik Dersine Bağlılık Ölçeği” kullanılmıştır.

Kişisel Bilgi Formu: Ortaokul öğrencilerinin cinsiyet, sınıf, yerleşim yeri, matematik dersi başarı notu, anne ve babanın eğitim durumu, matematik dersinden özel ders alma/yetiştirme kursuna katılma durumu, matematik öğretmeninin cinsiyeti, matematik öğretmenini sevme düzeyi, matematik önem düzeyi, matematik öz yeterlilik algısı gibi demografik bilgileri içeren sorulardan oluşmaktadır.

Matematik Dersine Bă̆lllık Ölçeği: Öğrencilerin matematik dersine bağlılıklarını belirlemek amacıyla Rimm-Kauffman (2010) tarafindan geliştirilen ve Türkçeye uyarlaması araştırmacılar tarafından yapılan "Matematik Dersine Bă̆lllık Ölçeği kullanılmıştır. Ölçek, bilişsel bağlılık (M10. Derste elimden geldiğince çok şey ögrrenmeye çalıştım.), duyuşsal bağlılık (M12. Derste problem çözmekten zevk aldım.) ve sosyal bağlılık (M2. Sinıfta matematik hakkında arkadaşlarla konuştuk.) olmak üzere bağlılığın üç boyutunu ele almaktadır. Ölçek, dörtlü likert tipinde (1=Katılmıyorum, 4= Tamamen Katılıyorum) olup ölçekte 12 olumlu, 1 olumsuz olmak üzere toplam 13 madde yer almaktadir.

\subsection{Verilerin Analizi}

Verilerin analizinde öncelikle, analizlerin uygunluğu ve varsayımların kontrolü için boş verilerin değerlendirilmesi, normallik testi, doğrusallık ve uç değerlerin belirlenmesi işlemleri yapılmıştır. Uç değerlerin belirlenmesi amacıyla ölçek toplam puanında standart sapmanın +3 ve -3 aralığ dışında kalanlar bireyler tespit edilerek analizden çıkarılmıştır. Ardından kayıp veri analizi sonucunda, kayıp verilerin dağılımının tesadüfî olduğu belirlenmiş, bu nedenle de kayıp verilerin yerine seri ortalaması alınarak doldurulmuştur (Tabachnick \& Fidell, 2012). Verilerin normal dağılımını incelemek için ölçek toplam puanın ilişkin basıklık ve çarpıklık katsayılarına bakılmıştır. Ölçek toplam puan dağılımında çarpıklık katsayısının -.583 ve basıklık katsayısının ise -.469 olduğu bulunmuş̧ur. Bu sonuca göre basıklık ve çarpıklık değerleri +1 ile -1 arasında olduğundan verilerin normal dağıldığ 1 ifade edilebilir (\%1 güven aralığı \pm 1.96$)$ (Liu, Marchewka, Lu $\& \mathrm{Yu}, 2005)$.

Türk kültüründe model uyumunu belirlemek için doğrulayıcı faktör analizine başvurulmuştur. Ölçek uyarlama çalışmalarında belirli bir kuramsal temel dayalı oluşturulmuş ve faktör yapısı önceden belli olan modellerin farklı dillerde ve kültürlerde doğrulanması söz konusu olduğundan doğrulayıcı faktör analizin tercih edilmesi gerektiği ifade edilmektedir (Watkins, 1989).

Faktör analizinden önce verilerin faktör analizi için uygunluğu test etmek ve değişkenler arasındaki ilişkiyi temsil eden korelasyon matrisinin anlamlılığını incelemek için Kaiser-Meyer-Olkin (KMO) ve Bartlett's küresellik testine başvurulmuştur (Tablo 1). 
Tablo 1. KMO ve Barlett'in küresellik testi sonuçları

\begin{tabular}{lcc}
\hline $\begin{array}{l}\text { Kaiser-Meyer-Olkin } \\
\text { Büyülkçümlerinü }\end{array}$ & Örneklem & .916 \\
\hline Bartlett'in Küresellik testi & Ki-kare & 2634.15 \\
& sd & 78 \\
& $p$ & .000 \\
\hline
\end{tabular}

KMO değerinin 0.60 'dan yüksek olması ve Barlett küresellik testinin anlamlı çıkması $(p<.05)$ verilerin faktör analizi için uygun olduğunu göstermektedir (Büyüköztürk, 2007). Tablo 1'den görüldüğü gibi bu çalışmada KMO değeri .91 olarak bulunarak örneklem yeterliliğin iyi düzeyde olduğu sonucuna varılmıştır. Barlett test sonucu 2634.15 $(p<.01)$ olarak hesaplanmış olup anlamlı bulunarak veri setinin faktör analizi için uygun olduğu belirlenmiştir.

Güvenirlik çalışmaları için ise ölçeğin tamamının ve faktör bazında iç tutarlılık katsayısı hesaplanmış, ayrıca test tekrar test güvenirliği incelenmiştir. Ölçekteki maddelerin analizi için madde toplam korelasyonları hesaplanmış ve maddelerin alt \%27 üst \%27'lik gruplar arasındaki madde puanları farkı $t$-testi ile incelenmiştir. Ölçek geliştirme çalışmalarında ölçeğin geçerliğini sağlamanın diğer bir yolu da ölçüt geçerliğinin sağlanmasıdır (Büyüköztürk, 2007). Ölçüt geçerliğinde, ölçeğin uygulandığı gruptan elde edilen puanların yine uygulama yapılan gruptan elde edilen ve ölçeğin ölçtüğü özelliklerin bulunduğu bir başka değişkenle (başarı, tutum, ilgi, vb.) ilişkisine bakılması söz konusudur. Nitekim alanyazında (Fredricks ve ark., 2004; Günüç \& Kuzu, 2015; Hughes \& Kwok, 2007; Hughes, Luo, Kwok, \& Loyd, 2008; Kong, Wong \& Lam 2003; Leis ve ark., 2014; Wang \& Holcombe, 2010) öğrenci bağlılığı ile akademik başarının birbiriyle ilişkili olduğu vurgulanmaktadır. Bu nedenle bu araştırma kapsamında matematik bağlılık ölçeğinin ölçüt geçerliği için öğrencilerin ölçeğin uygulandığı matematik dersi karne başarı notları ölçüt olarak kabul edilmiştir. Bu kapsamda matematik bağlılık ölçeği ile matematik dersi karne başarı notları arasındaki ilişkiyi belirlemek amacıyla Pearson korelasyon testi uygulanmıştır.

\section{Bulgular}

\subsection{Geçerlilik Çalıșmaları}

a) Matematik Dersine Bağglılık Ölçeği Birinci Düzey Doğrulayıcı Faktör Analizi

Orijinal ölçekte üç gizil değişken (bilişsel, duyuşsal ve sosyal) ve 13 gözlenen değişkenden (ölçek maddeleri) oluşan yapının doğrulanması amacıyla Lisrel 8.81 programı kullanılarak birinci düzey doğrulayıcı faktör analizi yapılmıştır.

Doğrulayıcı faktör analizlerinde ve yapısal eşitlik modellemelerinde modelin veriye uyumunun değerlendirilmesinde en genel kullanılan uyum indeksleri $\chi^{2}$ (ki-kare), RMSEA (Root Mean Square Error of Approximation), GFI (Goodness of Fit Index), AGFI (Adjusted Goodness of Fit Index), CFI (Comparative Fit Index) ve NNFI (Non-Normed Fit Index)'dır (Sümer, 2000). Bu değerlerden $\chi^{2} /$ sd oranının 5'ten küçük, RMSEA'nın 
0.08'den küçük, GFI değerinin 0.90'dan büyük, AGFI değerinin 0.80'den büyük, CFI değerinin 0.90 'dan büyük ve NNFI değerinin 0.90 'dan büyük olması modelin veriye uyumunun iyi olduğunu göstermektedir (Hartwick \& Barki, 1994; Segars \& Grover, 1993).

$\mathrm{Bu}$ çalışmada matematik bağlılık ölçeğinin birinci düzey doğrulayıcı faktör analizi sonucu ortaya çıkan uyum indeksleri Tablo 2'de verilmiştir.

Tablo 2. Ölçeğin birinci düzey doğrulayıcı faktör analizi uyum indeksleri

\begin{tabular}{ccc}
\hline Uyum İndeksi & Kabul Edilebilir Değer & Model Değeri \\
\hline$\chi 2 /$ sd & $<5$ & 2.70 \\
RMSEA & $<.08$ & 0.053 \\
GFI & $\geq .90$ & 0.96 \\
AGFI & $\geq .80$ & 0.94 \\
CFI & $\geq .90$ & 0.98 \\
NNFI & $\geq .90$ & 0.98 \\
\hline
\end{tabular}

Tablo 2'den görüldüğü gibi matematik dersine bağlllık ölçeğinin birinci düzey doğrulayıcı faktör analizinden elde edilen uyum indeksi değerleri $[\chi 2 / \mathrm{sd}=2.70, n=602$, $\chi 2=167.8, p<.000, \mathrm{RMSEA}=.053, \mathrm{GFI}=0.96, \mathrm{AGFI}=0.94, \mathrm{CFI}=0.98, \mathrm{NNFI}=0.98]$ olarak ortaya çıkmıştır. Bu değerler $\chi 2 /$ sd, RMSEA, GFI, CFI ve NNFI uyum indekslerinin kabul edilebilir düzeyde olduğunu göstermektedir.

Birinci Düzey Doğrulayıcı Faktör analizinin bağlantı diyagramı (path diagram) standart katsayılar Şekil 1'de ve $t$-testi değerlerini gösteren diyagram Şekil 2'de yer almaktadır. Şekil 2'de görüldüğü gibi ölçekte doğrulayıcı faktör analizine ilişkin her bir maddeye ait standardize çözümleme değerleri 0.28 ile 0.75 arasındadır. Kline (2005), standardize çözümleme değerlerinin 0.10 civarında olmasını düşük, 0.30 civarında olmasını orta, 0.59 ve üstünde olmasını ise yüksek kabul edilmesi gerektiğini belirtmiştir. $\mathrm{Bu}$ değerlerin yüksek olması maddenin ilgili faktörün geçerli göstergesi şeklinde yorumlanmaktadır. Şekil 3'de görüldügü gibi, ölçekte doğrulayıcı faktör analizine ilişkin her bir maddeye ait standardize çözümleme değerlerinin anlamlı olup olmadığını belirlemek için hesaplanan $t$-testi değerleri 8.40 ile 21.02 arasında değişmektedir. Hesaplanan bu $t$-testi değerlerin de tüm maddeler için anlamlı $(p<.01)$ olduğu bulunmuştur. 


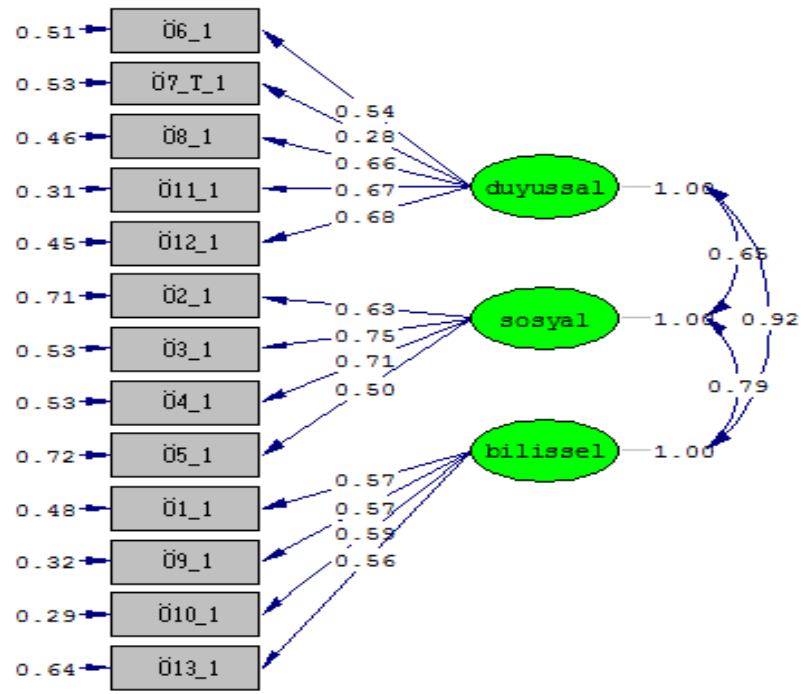

Şekil 1. Ölçeğin birinci düzey doğrulayıcı faktör analizi sosyal bağlantı diyagramı (standart katsayılar)

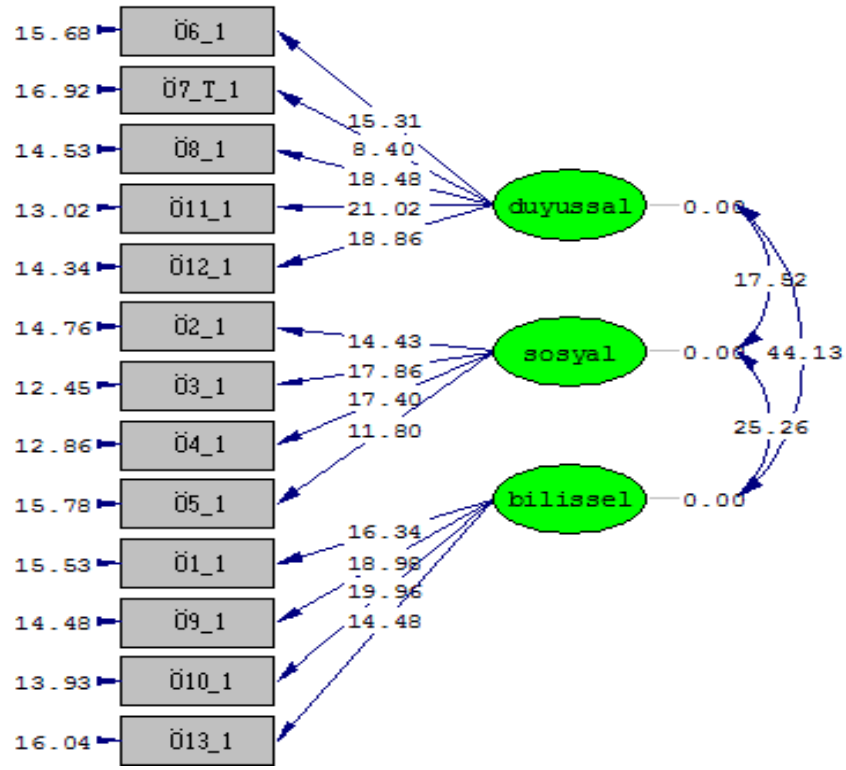

Şekil 2. Ölçeğin birinci düzey doğrulayıcı faktör analizi sosyal bağlantı diyagramı ( $t$-testi değerleri) 


\section{b) Matematik Dersine Bağlllık Ölçeği İkinci Düzey Doğrulayıcı Faktör Analizi}

Matematik dersine bağlılığa ilişkin ölçeğin birinci düzey doğrulayıcı faktör analizi ile elde edilen duyuşsal bağlılık, sosyal bağlılık ve bilişsel bağlılık boyutlarının kuramsal olarak ileri sürülen matematik dersine bağlılık faktörünü temsil ettiğini göstermek amacıyla bu üç boyutun bir üst boyutu olan matematik bağlılığı ikinci düzey değişkeni ile olan yapısal ilişkilerini veren ikinci düzey doğrulayıcı faktör modeli oluşturulmuştur. İkinci düzey faktör analizi ile ikinci düzey benimseme değişkeninin birinci düzey değişkenlerde açıkladığ 1 varyanslar da ortaya konulmuştur.

$\mathrm{Bu}$ çalışma kapsamında 3 gizil ve 13 gösterge değişken ile test edilen birinci düzey doğrulayıcı yapıya ikinci düzey matematik bağlılığı gizil değişkeni eklenerek ve ikinci düzey faktör modelinin test edilmesi sonucu uyum iyiliği değerleri Tablo 3 'de verilmiştir.

Tablo 3. Ölçeğin ikinci düzey doğrulayıcı faktör analizi uyum indeksleri

\begin{tabular}{ccc}
\hline Uyum İndeksi & Kabul Edilebilir Değer & Model Değeri \\
\hline$\chi 2 /$ sd & $<5$ & 2.70 \\
RMSEA & $<.08$ & .053 \\
GFI & $\geq .90$ & .96 \\
AGFI & $\geq .80$ & .94 \\
CFI & $\geq .90$ & .98 \\
NNFI & $\geq .90$ & .98 \\
\hline
\end{tabular}

Tablo 3 incelendiğinde ölçeğin ikinci düzey doğrulayıcı faktör analizinden elde edilen uyum indeksi değerleri $(\chi 2 / \mathrm{sd}=2.70, p<.000$, RMSEA=.053, GFI= 0.96, AGFI=0.94, $\mathrm{CFI}=0.98, \mathrm{NNFI}=0.98)$ olarak hesaplanmıştır. Bulunan bu değerleri incelendiğinde $\chi 2 / \mathrm{sd}$, RMSEA, GFI, CFI ve NNFI uyum indekslerinin kabul edilebilir düzeyde olduğunu göstermektedir.

İkinci Düzey Doğrulayıcı Faktör analizinin bağlantı diyagramı (path diagram) standart katsayılar Şekil 3'te ve $t$-testi değerlerini gösteren diyagram Şekil 4'te yer almaktadır. Şekil 3'de görüldüğü gibi ölçekte doğrulayıcı faktör analizine ilişkin bilişsel, duyuşsal ve sosyal bağlılık boyutuna ait standardize çözümleme değerleri sırasıyla $1.06,0.87$ ve 0.74 'tür. Kline (2005) standardize çözümleme değerlerinin 0.10 civarında olmasını düşük, 0.30 civarında olmasını orta, 0.59 ve üstünde olmasını ise yüksek kabul edilmesi gerektiğini belirtmiştir. Bu değerlerin yüksek olması faktörlerin ölçeğin kendisiyle ilgili olduğunu göstermektedir.

Şekil 4'de sunulan modelde görüldüğü gibi birinci düzey gizil değişkenler (duyuşsal bağlllık, sosyal bağlılık ve bilişsel bağlllık) ile ikinci düzey değişken olan matematik bağlılığı arasındaki standardize çözümleme değerlerinin anlamlı olup olmadığını belirlemek için hesaplanan $t$-testi değerleri Tablo 4 'te verilmiştir. 


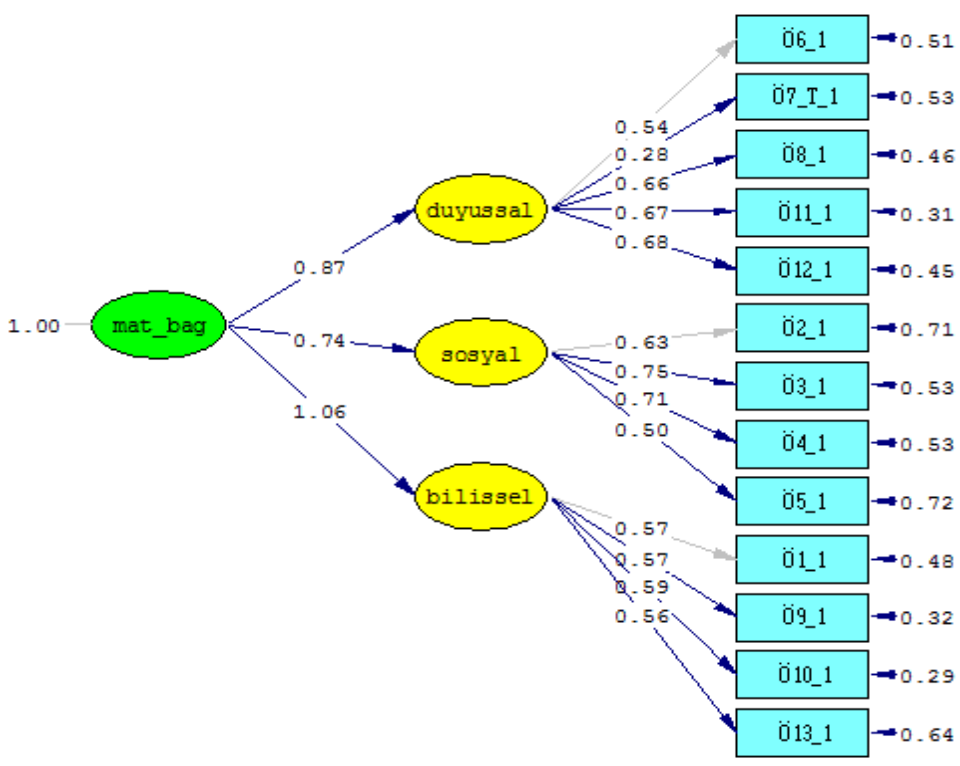

Şekil 3. Ölçeğin ikinci düzey doğrulayıcı faktör analizi bağlantı diyagramı (standart katsayılar)

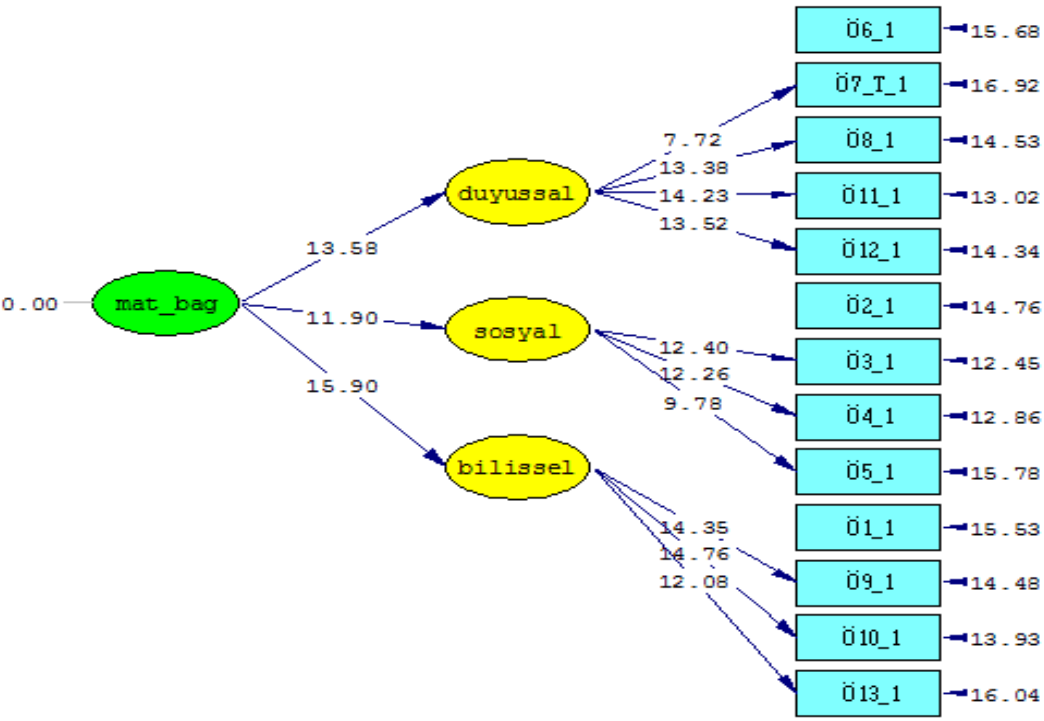

Şekil 4. Ölçeğin ikinci düzey doğrulayıcı faktör analizi bağlantı diyagramı ( $t$-değerleri) 
Tablo 4. Ölçeğin ikinci düzey doğrulayıcı faktör modeline ilişkin $t$-testi değerleri

\begin{tabular}{clc}
\hline \multirow{2}{*}{ İkinci Düzey Değişken } & Birinci Düzey & $t$-değeri \\
& Değişkenler & 13.58 \\
Matematik Dersine & Duyuş̧al Bağlılık & 11.90 \\
Bağlılık (mat_bag) & Sosyal Bağl1lık & 15.90 \\
\hline
\end{tabular}

Tablo 4'de görüldügü gibi ikinci düzey "mat_bag” gizil değişkeni ve birinci düzey gizil değişkenler arasındaki $t$-testi değerlerine bakkıldığında en yüksek ilişkinin bilişsel bağlılık ile matematik bağl1lığı arasında olduğu, ayrıca matematik bağlığı faktörü ile bu faktöre ilişkin 3 boyut arasında ilişkilerin tümünün pozitif yönlü ve anlamlı $(p<.05)$ olduğu ortaya çıkmıştır.

\section{c) Ölçüt geçerliliği}

$\mathrm{Bu}$ çalışma kapsamında ölçeğinin ölçüt geçerliği için öğrencilerin matematik dersi karne başarı puanları ölçüt olarak kabul edilmiştir. Matematik bağlılık ölçeği ile matematik dersi karne başarı puanları arasındaki ilişkiyi belirlemek amacıyla Pearson korelasyon katsayısı hesaplanmış, elde edilen sonuçlar Tablo 5'de sunulmuştur.

Tablo 5. Pearson korelasyon testi sonuçları $(n=602)$

\begin{tabular}{lccccc}
\hline Değişken & $\mathbf{1}$ & $\mathbf{2}$ & $\mathbf{3}$ & $\mathbf{4}$ & $\mathbf{5}$ \\
\hline 1. Karne Başarı Puanı & 1 & $.504^{* *}$ & $.418^{* *}$ & $.432^{* *}$ & $.527^{* *}$ \\
2.Bilişsel Bağl1lık Boyutu & & 1 & $.690^{* *}$ & $.590^{* *}$ & $.879^{* *}$ \\
3.Duyuşsal Bağll1ık Boyutu & & & 1 & $.489^{* *}$ & $.863^{* *}$ \\
4.Sosyal Bağl1lık Boyutu & & & & 1 & $.814^{* *}$ \\
5.Matematik Bağlllık Ölçeği & & & & & 1 \\
\hline
\end{tabular}

Tablo 5'de görüldüğü gibi matematik dersi karne başarı notu ile matematik bağlılık ölçeğinin alt boyutlarından bilişsel bağl1lık $(r=.504, \quad p<.01)$, duyuşsal bağlılık $(r=.418, p<.01)$, ve sosyal bağl1lık $(r=.432, p<.01)$ arasında pozitif yönlü orta düzeyde anlamlı bir ilişki olduğu saptanmıştır. Bezer şekilde matematik dersi karne başarı puanları ile matematik bağlılık ölçeği puanları arasında pozitif yönlü orta düzeyde anlamlı bir ilişki olduğu saptanmıştır $(r=.527, p<.01)$. Bu bulgular matematik başarı puanları ölçüt olarak ele alındığında matematik bağlılık ölçeğinin ölçüt geçerliğini sağladığını göstermektedir.

\subsection{Güvenirlik Analizleri}

Ölçeğin güvenirliğinin hesaplanmasında Cronbach alpha $(\alpha)$ güvenirlik katsayısı ve test tekrar test güvenirlik katsayısı incelenmiştir. Ölçeğin alt boyutları ve tümü için hesaplanan Cronbach alpha değerleri Tablo 6'da verilmiştir. 
Tablo 6. Matematik dersine bağlılık ölçeği faktörlerinin güvenirlik katsayısı

\section{Değişken}

Bilişsel Bağlılık

Duyuşsal Bağlılık

Sosyal Bağlılık

Ölçeğin Tümü

\section{Güvenirlik Katsayısı (Cronbach $\alpha$ )}

.752

.776

.722

.872

Tablo 6'da görüldüğü gibi matematik bağlılık ölçeğinin tümü için hesaplanan Cronbach alfa güvenirlik katsayısı .872 olup ölçeğin bilişsel, duyuşsal ve sosyal alt boyutları için hesaplanan Cronbach alfa güvenirlik katsayıları sırasıyla $.752, .776$ ve .722 olarak hesaplanmıştır. Bulunan bu değerler dikkate alındığında (>.70) ölçeğin güvenirliği için kabul edilebilir düzeyde (Büyüköztürk, 2007) olduğu söylenebilir.

$\mathrm{Bu}$ çalışma kapsamında ölçeğin test tekrar test güvenirliği için 30 ortaokul öğrencisine ölçek formu iki hafta arayla tekrarlı olarak uygulanmıştır. İki uygulama arasındaki pearson korelasyon katsayısı $r=.591$ olarak hesaplanmış olup anlamlı bir ilişki olduğu saptanmıştır $(p<.05)$.

\subsection{Madde analizleri}

Matematik bağl1lığ $\% 27$ 'lik alt ve üst grupların madde puanlarındaki farklar incelenmiștir. Ayrıca, matematik bağl1lı̆̆ amacıyla madde toplam korelasyon katsayıları hesaplanmıştır. Alanyazında madde toplam korelasyonun .20 ve üzeri olması gerektiği ifade edilmektedir (Kline, 1993). Bu çalışma kapsamında ölçek maddelerine ilişkin madde-toplam korelasyon değerleri Tablo 7'de verilmiştir.

Tablo 7. Matematik dersine bağlılık ölçeği madde toplam korelasyonları

\begin{tabular}{lccc}
\hline Faktör & Madde & Madde-Toplam Korelasyonu & $\begin{array}{c}\text { Madde Silindiğinde } \\
\text { Cronbach Alpha }\end{array}$ \\
\hline \multirow{3}{*}{ Duyuşsal Bağl1lık } & Ö6 & .530 & .863 \\
& Ö7 & .295 & .874 \\
& Ö8 & .594 & .860 \\
& Ö11 & .658 & .856 \\
Ö12 & .641 & .857 \\
Ö2 & .522 & .864 \\
& Ö3 & .551 & .862 \\
& Ö4 & .516 & .864 \\
& Ö5 & .423 & .870 \\
Bilişsel Bağl1lık & Ö1 & .585 & .860 \\
& Ö9 & .634 & .858 \\
& Ö10 & .654 & .857 \\
& Ö13 & .524 & .864 \\
\hline
\end{tabular}


Tablo 7 incelendiğinde ölçekteki tüm maddelerin madde-toplam korelasyon değerleri .292 ile .658 arasında olup .20 ve üzeri çıkmıştır. Tablo 7'de her bir maddenin güvenirliğe katkısını gösteren madde silindiğinde hesaplanan Cronbach alpha değerleri incelendiğinde herhangi bir maddenin ölçekten atılmasının güvenirliği (.872) büyük ölçüde arttırmadığı da belirlenmiştir.

Ölçekte yer alan maddelerin ayırt edicilik güçlerini belirlemek amacıyla, her bir madde için üst grup ve alt grup puan ortalamaları arasındaki farkın anlamlı olup olmadığı bağımsız örneklemler için $t$-testi ile sınanmıştır (Tablo 8). Bunun için ölçek toplam puanları yüksekten düşüğe doğru sıralanmış, alt ve üst gruplar çalışma grubunun $\% 27$ 'sini oluşturacak şekilde (163'er kişi) iki gruba ayrılmıştır. Tablo 8 'de görüldüğü gibi ölçek maddelerine ilişkin alt ve üst grupların puanları için yapılan bağımsız örneklemler için $t$ testi sonucunda $t$-değerlerinin 8.83 ile 22.196 arasında yer aldığ ve her bir ölçek maddesine ilişkin alt ve üst grup puanları arasında üst grup lehine anlamlı fark olduğu saptanmıştır $(p<.01)$. Analiz sonucunda anlamlı farkın elde edilmesi, maddelerin bireyleri ölçülen davranış bakımından ayırt ettiğini göstermektedir (Büyüköztürk, 2007).

Tablo 8. Ölçek puanlarının \%27’lik alt ve üst gruplara ilişkin $t$-testi sonuçları

\begin{tabular}{|c|c|c|c|c|c|c|c|}
\hline \multirow{2}{*}{ Faktör } & \multirow{2}{*}{ Madde } & \multicolumn{2}{|c|}{ Alt Grup (\%27) } & \multicolumn{2}{|c|}{ Üst Grup (\%27) } & \multirow[b]{2}{*}{$t$} & \multirow[b]{2}{*}{$p$} \\
\hline & & Ort. & SS & Ort. & Ss & & \\
\hline \multirow{5}{*}{ Duyuşsal Bağlılık } & Ö6 & 2.62 & 1.03 & 3.91 & .29 & 15.38 & .000 \\
\hline & Ö7 & 3.21 & .94 & 3.91 & .35 & 8.83 & .000 \\
\hline & Ö8 & 2.22 & .87 & 3.82 & .44 & 20.74 & .000 \\
\hline & Ö11 & 2.36 & .86 & 3.92 & .28 & 21.86 & .000 \\
\hline & Ö12 & 2.23 & .91 & 3.91 & .30 & 22.19 & .000 \\
\hline \multirow{4}{*}{ Sosyal Bağlılık } & Ö2 & 1.85 & .78 & 3.54 & .73 & 20.05 & .000 \\
\hline & Ö3 & 2.02 & .94 & 3.65 & .61 & 18.48 & .000 \\
\hline & Ö4 & 2.15 & .90 & 3.77 & .47 & 20.19 & .000 \\
\hline & Ö5 & 2.47 & .97 & 3.76 & .50 & 15.11 & .000 \\
\hline \multirow{4}{*}{ Bilişsel Bağlılık } & Ö1 & 2.31 & .80 & 3.76 & .49 & 19.67 & .000 \\
\hline & Ö9 & 2.60 & .90 & 3.95 & .20 & 18.55 & .000 \\
\hline & Ö10 & 2.63 & .89 & 3.95 & .21 & 18.27 & .000 \\
\hline & Ö13 & 2.22 & .89 & 3.75 & .57 & 18.35 & .000 \\
\hline
\end{tabular}

\section{Bulgular ve Yorum}

$\mathrm{Bu}$ çalışmada ortaokul öğrencilerinin matematik dersine olan bağlılık düzeylerine etki eden faktörleri ortaya koymak amacıyla Rimm-Kauffman (2010) tarafından geliştirilen "Matematik Dersine Bağlılık Ölçeği” Türkçeye uyarlanmış (Bkz. Ek - 1); geçerlilik ve güvenirlilik sonuçları raporlanmıştır. Matematik bağlılık ölçeğinin doğrulayıcı faktör analizi sonuçları ile 3 faktörlü ve 13 madden oluşan yapı olduğu kuramsal ve istatistiksel olarak doğrulanmıştır. Matematik bağlılığına etki eden faktörler duyuşsal, sosyal ve 
bilişsel faktörler olarak bulunmuştur. Ölçeğin tamamının iç tutarlılık katsayısı .872 olarak bulunurken, test tekrar güvenirlik korelasyon katsayısı .591 olarak hesaplanmıştır.

Yapılan doğrulayıcı faktör analizi sonucunda bağl1lık ölçeği ile bilişsel bağlılık alt boyutu arasındaki ilişkinin anlamlı ve pozitif yönlü olduğu $(t=15.90, p<.01)$ saptanmış olup bilişsel boyutunun iç tutarlılık katsayısı .752 olarak hesaplanmıştır. Bağlılık ölçeği ile sosyal bağlılık alt boyutu arasındaki ilişkinin de anlamlı ve pozitif yönlü olduğu $(t=611.90, p<.01)$ belirlenmiştir. Sosyallik boyutunun iç tutarlılık katsayısı ise .722 olarak hesaplanmıştır. Diğer yandan bağl1lık ölçeği ile duyuşsal bağlılık alt boyutu arasındaki ilişki anlamlı ve pozitif $(t=13.58, p<.01)$ olarak bulunmuş ve duyuşsal boyutunun iç tutarlılık katsayısı .776 olarak hesaplanmıştır.

$\mathrm{Bu}$ çalışmada yapılan madde analizi sonucunda ölçekte yer alan maddeler için maddetoplam korelasyon değerlerinin de .292 ile 658 arasında değer aldığı, ölçek maddelerinin ayıt ediciliğini belirlemek amacıyla \%27'lik alt ve üst gruplar için yapılan $t$-testi sonucunda anlamlı fark saptanmış $(p<.01)$ olup ölçek maddelerinin ayırt edici nitelikte olduğu belirlenmiştir.

Bu çalışma kapsamında ölçeğin ölçüt geçerliği belirlemek amacıyla matematik dersi karne başarı notları ölçüt olarak kabul edilmiş, bağlılık ölçeği ile matematik dersi karne başarı puanları arasındaki pozitif yönlü orta düzeyde anlamlı bir ilişki saptanmıştır $(r=.533, p<.01)$. Bu yönüyle ölçeğin ölçüt geçerliğini de sağladığı belirlenmiştir.

\section{Sonuç ve Öneriler}

$\mathrm{Bu}$ araştırma sonucunda matematik bağ l1lığ 1 ölçeğine ilişkin üç faktörün de (duyuşsal, sosyal ve bilişsel) matematik bağlılığ ile anlamlı ve olumlu ilişkide olduğu görülmüş ve hesaplanan güvenirlik katsayısı değerleri ile ölçeğin tümünün ve alt boyutlarının güvenilir olduğu bulunmuştur.

Matematik bağlılığına etkileyen faktörleri ortaya koyan bu çalışmanın Türkiye'de alan yazınında az bulunan öğrenci bağlılığıyla ilgili ölçme araçlarına katkı sağlayacağ 1 ve bu faktörler üzerinde yeni çalışmalar yapılmasına olanak tanıyacağı düşünülmektedir.

Geçerlilik ve güvenirlilik çalışmaları yapılan bu ölçekle matematik dersine ilişkin duyuşsal, sosyal ve bilişsel bağlılığa ilişkin faktörler ölçülebilir. Ayrıca ilerideki çalışmalar da bu ölçme aracına yeni boyutlar eklenip geçerlik ve güvenirlik çalışmaları yapılarak matematik bağlılığı sürecinde etkin olan farklı faktörler de açıklanabilir.

Matematik bağlılığını arttırmanın matematik dersindeki başarıyı ve motivasyonu da arttıracağ1 (Fredricks ve ark., 2004; Günüç \& Kuzu, 2015; Hughes \& Kwok, 2007; Hughes ve ark., 2008; Kong, Wong \& Lam, 2003; Leis ve ark., 2014; Reeve, Jang, Carell, Jeon \& Barch, 2004; Wang \& Holcombe, 2010) varsayımından yola çıarak, ileriki çalışmalarda öğrencilerin matematik bağlılık düzeyleri ve matematik başarıları arasındaki ilişki incelenebilir. Ayrıca matematik bağlılığı düşük olan öğrenciler matematik bağlılığını arttırıcı etkinliklerle desteklenerek matematik başarısındaki artış incelenebilir. 
Rimm-Kaufmann ve ark. (2014) yaptıkları çalışmada öğrencilerin matematik dersine ilişkin bağlılığını araştırmacının gözlemi, öğrencilerin kendilerinin raporladığı bağlılık ve öğretmenler tarafından raporlanan bağlılık olmak üzere üç farklı kaynaktan elde ederek aralarındaki korelasyona bakmışlardır. Ölçeklerden elde edilen puanlar bireyin kendisi tarafından raporlanan sübjektif yanıtlar olduğu için, Türkçe geçerlilik ve güvenirliği sağlanan ölçeğin kullanıldığı araştırmalarda da ölçekten elde edilen puanların geçerliliğini arttırmak için öğretmen değerlendirmesi, araştırmacı gözlemi gibi farklı kaynaklardan da veriler toplanabilir. 


\section{Adaptation of Student Engagement in Mathematics Scale into Turkish}

\section{Extended Abstract}

\section{Introduction}

Math is an important science both in daily life and academic settings. Nevertheless either global standard tests or evaluations in national levels reveal that math is perceived as a difficult course and achievement is lower than expected level is not just a concern for particular countries, but has become a global concern over the years (Mohamed \& Waheed, 2011; OECD, 2004). Many studies from past to present aimed to determine which variables are more effective in predicting math success. Among those variable, student's ability, attitude, perception, belief, motivation, self-efficacy, self-regulation, self-esteem, selfconfidence, socio-economic variables, parent/peer effect and variables related to school are some of which are frequently examined in research (Nicolaidou \& Philippou, 2003; Singh, Granville \& Dika, 2002).

As seen in literature, as well as there are lots of variables which effect math success or failure, one of these variables which is seen highly related with student success is "engagement" concept. It has been suggested that increasing engagement in math course will also increase the math success and revealing out the engagement will be the indicator of motivation (Leis, Schmidt, \& Rimm-Kaufman, 2014; Reeve, Jang, Carell, Jeon \& Barch, 2004).

Rimm-Kauffman (2010) has developed "Student Engagement in Mathematics Scale" to assess children's engagement in mathematics after a math class. The scale measures three dimensions of engagement: social, cognitive, and emotional. The purpose of this study is to adapt "Student Engagement in Mathematic Scale", to Turkish and provide validity and reliability of the Turkish form.

\section{Methodology}

The study group is consisted of 602 secondary school students. The original scale consisted of 13 Likert-type items under three factors (social, emotional and cognitive) designed to assess students 'engagement in mathematics after a math class. These items used four point response scale ( $1=$ no, not all true to $4=$ yes, very true) and prompted students to indicate the degree to which they agreed with each statement. Students are asked to complete the measure immediately after a math class. After translation studies, scale was conducted to study group.

Before the validity and reliability analysis, firstly missing data, normality and linearity analysis were checked out. After data screening, first order and second order confirmatory factor analyses were executed to show construct validity. Students' math lesson success grade was used for criterion validity. Reliability studies was conducted by measuring Cronbach's Alpha $(\alpha)$ and test-retest reliability coefficient was calculated. For the item 
analysis, item total correlation was calculated and $27 \%$ upper /lower group item score differences were examined by $\mathrm{t}$ test.

\section{Findings}

First order confirmatory factor analysis was executed on the model of 3 latent variables (cognitive, emotional, and social) in the original scale and 13 observed variables (items). As a result of analysis, fit indices values were found as $[\chi 2 / \mathrm{sd}=2.70, \mathrm{~N}=602, \chi 2=167.8, \mathrm{p}<.000$, RMSEA $=.053, \mathrm{GFI}=0.96$, AGFI $=0.94, \mathrm{CFI}=0.98, \mathrm{NNFI}=0.98]$. The values of $\chi 2 / \mathrm{sd}$, RMSEA, NNFI, GFI, AGFI, S-RMR and CFI were found to be in good fit.

A second order confirmatory factor model was performed to show if the first order factors (cognitive, emotional, and social) were indicator of the theoretically proposed higher order factor, "engagement in mathematics". As a result of analysis fit indices values were found $[\chi 2 / \mathrm{sd}=2.70, \mathrm{~N}=602, \chi 2=167.8, \mathrm{p}<.000, \mathrm{RMSEA}=.053, \mathrm{GFI}=0.96, \mathrm{AGFI}=0.94, \mathrm{CFI}=0.98$, $\mathrm{NNFI}=0.98]$.

For the criterion validity, correlation between students' math lesson success grade and engagement in math was examined. Correlation coefficient was found to be $(r=.527$, $p<.01)$ which shows a positive significant correlation. Cronbach alpha coefficient was found to be, 872 . For the test-retest reliability engagement in mathematics scale was applied to 30 students two times two week interval. Correlation coefficient between two administration was found to be $.591(\mathrm{p}<.05)$ which indicated stability of instrument. All the item total correlations was found to be over .20 and ranged between .295 and .658 . The differences between mean scores of lower $27 \%$ and upper $27 \%$ groups were significant $(\mathrm{p}<.001)$ for each item which shows discrimination power of scale items.

\section{Conclusion}

This study has adapted the "Student Engagement in Mathematics Scale", developed by Rimm-Kauffman (2010), into Turkish. Analysis of the results of this study indicated that Turkish form of the scale is reliable and valid. This scale can contribute to instruments related engagement which is in short supply in Turkish literature and also enable new research on those factors. This scale can be used to measure emotional, cognitive and social factors related to math course. In future studies, using this scale, experimental studies can be designed to increase engagement in mathematics. Moreover new construct can be added to scale to explain different factors that affect engagement in math. 


\section{Kaynaklar/References}

Baki, A. (2008). Kuramdan uygulamaya matematik eğitimi. Ankara: Harf yayınları.

Bingham, G. E., \& Okagaki, L. (2012). Ethnicity and student engagement. In Christenson, S. L., Reschly, A. L \& Wylie, C. (Eds.), Handbook of research on student engagement (pp. 65-95). New York: Springer US.

Birgin, O., Baloğlu, M., Çatlığlu, H., \& Gürbüz, R. (2010). An investigation of mathematics anxiety among sixth through eighth grade students in Turkey. Learning and Individual Differences, 20(6), 654-658.

Büyüköztürk, Ş. (2007). Veri analizi el kitabl (7. Baskı). Ankara: PegemA Yayıncılık.

Büyüköztürk, Ş., Çakan, M., Tan, Ş. ve Atar, H. Y. (2014). TIMSS 2011 ulusal matematik ve fen raporu: 4.sinıflar. Ankara: İşur Matbaacılık.

Chen, P. D., Kuh, G. D., \& Gonyea, R. M. (2008). Learning at a distance: engaged or not? Innovate Journal of Online Education, 4(3), (pp.1-8).

Christenson, S. L., Reschly, A. L., Appleton, J. J., Berman-Young, S., Spanjers, D. M., \& Varro, P. (2008). Best practices in fostering student engagement. In A. Thomas \& J. Grimes (Eds.), Best practices in school psychology (5th ed., pp. 1099-1119). Bethesda, MD: National Association of School Psychologists.

Cleary, T. J., \& Zimmerman, B. J. (2012). A cyclical self-regulatory account of student engagement: Theoretical foundations and applications. In Christenson, S. L., Reschly, A. L \& Wylie, C. (Eds.), Handbook of research on student engagement (pp. 237-257). New York: Springer US.

Doğan, U. (2014). Validity and reliability of student engagement scale. Bartın Üniversitesi Eğitim Fakültesi Dergisi, 3(2), 390-403.

Dursun, Ş. ve Dede, Y. (2004). Öğrencilerin matematikte başarısını etkileyen faktörler matematik öğretmenlerinin görüşleri bakımından. Gazi Üniversitesi Gazi Ĕgitim Fakültesi Dergisi, 24(2), 217-230.

Ergün, E. ve Usluel, Y. (2015). Çevrimiçi öğrenme ortamlarında öğrenci bağlılık ölçeğinin Türkçe uyarlaması: Geçerlik ve güvenirlik çalışması. Eğitim Teknolojisi Kuram ve Uygulama, 5(1), 20-33.

Finn, J. D. (1989). Withdrawing from school. Review of Educational Research, 59, 117142.

Finn, J. D., \& Zimmer, K. S. (2012). Student engagement: What is it? Why does it matter? In Christenson, S. L., Reschly, A. L \& Wylie, C. (Eds.), Handbook of research on student engagement (pp. 97-131). New York: Springer US..

Fredericks, J. A., Blumenfeld, P. C., \& Paris, A. H. (2004). School engagement: potential of the concept, state of the evidence. Review of Educational Research, 74, 59-109.

Günüç, S., \& Kuzu, A. (2015). Student engagement scale: Development, reliability and validity. Assessment \& Evaluation in Higher Education, 40(4), 587-610.

Hartwick, J., \& Barki, H. (1994). Explaining the role of user participation in information system use. Management Science, 40(4), 440-465. 
Hughes, J., \& Kwok, O. M. (2007). Influence of student-teacher and parent-teacher relationships on lower achieving readers' engagement and achievement in the primary grades. Journal of Educational Psychology, 99(1), 39.

Hughes, J. N., Luo, W., Kwok, O., \& Loyd, L. K. (2008). Teacher-student support, effortful engagement, and achievement: a three-year longitudinal study. Journal of Educational Psychology, 1, 1-14.

Klaasen, R., M., Yerdelen, S., \& Durksen, T. (2013). Measuring teacher engagement: development of the engaged teachers scale (ets). Frontline Learning Research, 2, 3352.

Kline, P. (1993). A handbook of test construction. London, UK: Routledge.

Kline, R.B. (2005), Principles and Practice of Structural Equation Modeling (2nd Edition ed.). New York: The Guilford Press.

Kong, Q. P., Wong, N. Y., \& Lam, C. C. (2003). Student engagement in mathematics: development of instrument and validation of construct. Mathematics Education Research Journal, 15, 4-21.

Krause, K., \& Coates, H. (2008). Students' engagement in first-year university. Assessment and Evaluation in Higher Education, 33(5), 493-505.

Leis, M., Schmidt, K. M., \& Rimm-Kaufman, S. E. (2014). Using the partial credit model to evaluate the student engagement in mathematics scale. Journal of Applied Measurement, 16(3), 251-267.

Liu, C., Marchewka, J. T., Lu, J., \& Yu, C. S. (2005). Beyond concern: A privacy-trust behavioral intention model of electronic commerce. Information \& Management, 42, 289-304.

Ma, X. (1997). Reciprocal relationships between attitude toward mathematics and achievement in mathematics. The Journal of Educational Research, 90(4), 221-229.

Mazer, J. P. (2013). Validity of the student interest and engagement scales: Associations with student learning outcomes. Communication Studies, 64, 125-140.

Milli Eğitim Bakanlığı [MEB]. (2016). 2015-2016 eğitim-öğretim yılı 1. dönem ortak sinavı test ve madde istatistikleri. Ankara: MEB Ölçme Değerlendirme ve Sınav Hizmetleri Genel Müdürlügü.

Meece, J. (2009). Measure of student cognitive engagement. Unpublished measure, University of North Carolina.

Mohamed, L., \& Waheed, H. (2011). Secondary students' attitude towards mathematics in a selected school of Maldives. International Journal of humanities and social science, 1(15), 277-281.

Nicolaidou, M., \& Philippou, G. (2003). Attitudes towards mathematics, self-efficacy and achievement in problem solving. European Research in Mathematics Education III. Pisa: University of Pisa.

Organization for Economic Co-operation and Development [OECD]. (2004). Learning for tomorrow's world: First results from PISA 2003. Paris: OECD Publications. 
Papanastasiou, C. (2002). Effects of background and school factors on the mathematics achievement. Educational Research and Evaluation, 8(1), 55-70.

Patrick, H., Ryan, A. M., \& Kaplan, A. (2007). Early adolescents' perceptions of the classroom social environment, motivational beliefs, and engagement. Journal of Educational Psychology, 99, 83-98.

Peker, M. ve Mirasyedioğlu, Ş. (2003). Lise 2. sınıf öğrencilerinin matematik dersine yönelik tutumları ve başarıları arasındaki ilişki. Pamukkale Üniversitesi Eğitim Fakültesi Dergisi, 14(2), 157-166.

Pekrun, R., \& Linnenbrink-Garcia, L. (2012). Academic emotions and student engagement. In Christenson, S. L., Reschly, A. L \& Wylie, C. (Eds.), Handbook of research on student engagement (pp. 259-282). New York: Springer US.

Reeve, J., Jang, H., Carrell, D., Jeon, S., \& Barch, J. (2004). Enhancing students' engagement by increasing teachers' autonomy support. Motivation and Emotion, 28(2), 147-169.

Rimm-Kaufman, S. E. (2010). Student engagement in mathematics scale (SEMS). Unpublished measure, University of Virginia, Charlottesville, VA.

Rimm-Kaufman, S. E., Baroody, A. E., Larsen, R. A., Curby, T. W., \& Abry, T. (2015). To what extent do teacher-student interaction quality and student gender contribute to fifth graders' engagement in mathematics learning?.Journal of Educational Psychology, 107(1), 170.

Rowley, S. J., Kurtz-Costes, B., Meyer, R., \& Kizzie, K. (2009). Engagement and selfconcept during the transition to middle school: Gender and domain-specific differences in change in African American youth. Unpublished manuscript, University of Michigan.

Savaş, E., Taş, S. ve Duru, A. (2010). Matematikte öğrenci başarısını etkileyen faktörler. İn̈̈n̈̈ Üniversitesi Eğitim Fakültesi Dergisi, 11(1), 113-132.

Segars, A. H., \& Grover, V. (1993). Re-examining perceived ease of use and usefulness: A confirmatory factor analysis. MIS Quarterly, 17(4), 517-525.

Singh, K., Granville, M., \& Dika, S. (2002). Mathematics and science achievement: Effects of motivation, interest, and academic engagement. The Journal of Educational Research, 95(6), 323-332.

Skinner, E. A., \& Belmont, M. J. (1993). Motivation in the classroom: Reciprocal effects of teacher behavior and student engagement across the school year. Journal of Educational Psychology, 85, 571-581.

Skinner, E. A., \& Pitzer, J. R. (2012). Developmental dynamics of student engagement, coping, and everyday resilience. In Christenson, S. L., Reschly, A. L \& Wylie, C. (Eds.), Handbook of research on student engagement (pp. 21-44). New York: Springer US.

Sun, J. C. Y., \& Rueda, R. (2012). Situational interest, computer self-efficacy and self regulation: Their impact on student engagement in distance education. British Journal of Educational Technology, 43(2), 191-204.

Sümer, N. (2000). Yapısal eşitlik modelleri: Temel kavramlar ve örnek uygulamalar, Türk Psikoloji Yazılarl, 3(6), 49-73.

Stovall, I. (2003). Engagement and online learning. UIS community of practice for elearning. Retrieved from http://otel.uis.edu/copel/EngagementandOnlineLearning.ppt 
Tabachnick, B. G., \& Fidell, L. S. (2007). Using multivariate statistics. Boston: Pearson/Allyn \& Bacon.

Uğur, E., \& Akın, A. (2015). The psychometric properties of Turkish version of the student engagement scale. SDU International Journal of Educational Studies, 2(1), 53-59.

Wang, M. T., \& Holcombe, R. (2010). Adolescents' perceptions of school environment, engagement, and academic achievement in middle school. American Educational Research Journal, 47, 633-642.

Watkins, D. (1989). The role of confirmatory factor analysis in cross-cultural research. International Journal of Psychology, 24, 685-701.

Willms, J. D. (2003). Student engagement at school: A sense of belonging and participation: Results from PISA 2000. Paris, Fr: Organization for Economic Cooperation and Development.

\section{Kaynak Gösterme}

Mazman-Akar, S. G., Birgin, O., Göksu, B., Uzun, K., Gümüş, B. ve Peker, E. S. (2017). Matematik Dersine Bağlılık Ölçeği'nin Türkçeye uyarlama çalışması. Türk Bilgisayar ve Matematik Eğitimi Dergisi, 8(1), 285-303.

\section{Citation Information}

Mazman-Akar, S. G., Birgin, O., Göksu, B., Uzun, K., Gümüş, B., \& Peker, E. S. (2017). Adaptation of Student Engagement in Mathematics Scale into Turkish. Turkish Journal of Computer and Mathematics Education, 8(1), 285-303. 
Ek - 1. Matematik Dersine Bağlılık Ölçeği

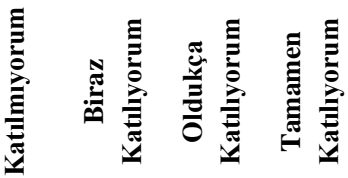

\begin{tabular}{llllll}
\hline 1. & Derste elimden geldiğince sıkı çalıştım. & 1 & 2 & 3 & 4 \\
\hline 2. & Sınıfta matematik hakkında arkadaşlarla konuştuk. & 1 & 2 & 3 & 4 \\
\hline 3. & $\begin{array}{l}\text { Derste arkadaşlarımın yapamadığı şeyler olduğu zaman onlara yardım } \\
\text { ettim. }\end{array}$ & 1 & 2 & 3 & 4 \\
\hline 4. & Derste arkadaşlarımla fikir ve materyal paylaşımında bulundum. & 1 & 2 & 3 & 4 \\
\hline 5. & Derste arkadaşlar birbirine yardım etti. & 1 & 2 & 3 & 4 \\
\hline 6. & Ders çok eğlenceliydi. & 1 & 2 & 3 & 4 \\
\hline 7. & Derste sıkıldım. & 1 & 2 & 3 & 4 \\
\hline 8. & Bugün matematik hakkında düşünmek hoşuma gitti. & 1 & 2 & 3 & 4 \\
\hline 9. & Bugün matematiği iyi anlamış olmak benim için önemliydi. & 1 & 2 & 3 & 4 \\
\hline 10. & Derste elimden geldiğince çok şey öğrenmeye çalıştım. & 1 & 2 & 3 & 4 \\
\hline 11. & Matematikle bir şeyler öğrenmek bugün benim için oldukça ilgi & 1 & 2 & 3 & 4 \\
\hline çekiciydi. & Derste problem çözmekten zevk aldım. & 1 & 2 & 3 & 4 \\
\hline 12. & Matematik dersin oldukça çok düşündüm. & 1 & 2 & 3 & 4 \\
\hline
\end{tabular}

